many of the shibboleths of just war theory, such as the 'double-effect' argument and the concept of legitimate authority but, on the other, an overall line of argument is difficult to trace. There is a thesis that emerges at the end, namely, that today's international terrorists have just as much right as states to avail themselves of just war arguments in deploying force, and taken from his perspective, a great deal of conventional western thinking can be portrayed as embodying double standards. This thesis seems to me though not to be sustained throughout the book, so what in effect we are presented with is a series of essays about just war thinking. As such, it is a most welcome intervention. I agree with the author that there is room for scepticism about present-day just war theory: many of its advocates remain the 'sorry comforters' that Kant took to task. They deplore the violence of the international system while inadvertently adding to it with their codices for the appropriate use of military force. However, Steinhoff's approach endangers his own cause by being over polemical and by its confusing deployment of both seemingly deontological arguments and consequentialist reasoning. On my reading - which of course may be deficient - it is difficult to tell whether or not Steinhoff embraces fully or partially rejects ruleutilitarianism (pp. 103, 135) although I have the impression that it is nonetheless the centrepiece of the moral argument.

\title{
Justifying the obligation to die: War, ethics and political obligation with illustrations from Zionism
}

\author{
Ilan Zvi Baron \\ Lexington Books, Lanham, MD, 2009, xxiv + 270pp., £49.95/\$80, \\ ISBN: 978-0739129739
}

Contemporary Political Theory (2011) 10, 506-508. doi:10.1057/cpt.2010.24

This is a fascinating, stimulating, but at times problematic, even irritating book. Ilan Zvi Baron's starting point is the observation that while the 
contemporary literature on the ethics of war has much to say about the act of killing at the behest of the state, it is less interested in the obligation to die for the state; an exception is a Vietnam-War era paper by Michael Walzer from which Baron takes his rather misleading title - misleading because what is at issue is actually the obligation to risk one's life for the state, not necessarily to die for it. Baron does not explain why this gap emerges, discounting a little too readily, I think, the importance of the ending of conscription in the AngloAmerican world, arguing that in modern times most conscripts were not actually put in harm's way - which is hardly true of, for example, World War I or Vietnam and, in any event, in principle, even, say, conscripted cooks could indeed be required to risk their lives and sometimes actually were. Still, instead of explaining the gap in the literature, Justifying the Obligation to Die is intended to fill it. It does so by engaging variously with the Just War tradition (Augustine and Aquinas in particular), the wider literature on political obligation and the nature of the state as a community (Aristotle, Hegel, Walzer), and contract and consent theories (Hobbes, Rousseau) as well as more salvation-oriented religious accounts of political obligation. All these bodies of work are brought to bear on Zionism as a political, ethical and religious phenomenon, with the work of Hannah Arendt employed as a kind of overseer of the engagement.

The focus on Zionism and Arendt works well. Traditional Jewish thought has not been centred on the kinds of political organisations that were capable of asking their members to risk their lives on their behalf; Zionism has at times made this demand and that makes it an interesting focus for an engagement with that Western political tradition which focuses the circumstances under which the community/state is entitled to require of its members the supreme sacrifice. Hannah Arendt is a valuable and challenging interlocutor here; as a Jewish thinker whose work is saturated in the Western tradition and who places great value on the political community but who, contra some strands of Zionism, favours diversity and pluralism, she provides a firm basis for Baron's conclusion, which is that a pluralist and diverse society that offers its members the opportunity to live the good life has a qualified right to ask them to risk their lives in its defence.

This is a compelling position, but in the book as a whole there is rather too much going on and the sections that are not oriented towards Zionism and Arendt are less successful. The short accounts offered here of figures such as Aristotle, Aquinas and so on do very little work; it simply isn't possible to get across what Aristotle or Aquinas meant by the good life in a few pages, and equally figures such as Hobbes and Rousseau defy the even more cursory treatment they are given here. It is not so much that Baron's judgements are wrong - although I'm not actually convinced that, for example, the author quite understands the significance of the fact that Hobbes's sovereign is not a 
party to the Hobbesian contract, or that Michael Walzer was heavily influenced by Hegel - more that if you are going to engage with such complex thinkers you need to allow yourself the space to do so properly, which would require a much more substantial book. By way of contrast, the extended engagement with Zionism is well executed and fascinating - along, I suspect, with most readers of this review, I am not well versed in the Zionism literature and here I found the short portraits of previously unknown figures such as Max Nordau and Abraham Kook very valuable. These sections of the book are also valuable because the thinkers in question are contextualised; as a result of Baron's scholarship we understand not only what they wrote or why they wrote it, but also what they hoped to do though their writings. Equally, while Hannah Arendt is the opposite of unknown - the Arendt industry appears to be unstoppable - Baron still manages the difficult feat of saying something new and interesting about her and her work.

This book began life as what was obviously a very good $\mathrm{PhD}$ thesis - the problem is that it hasn't evolved sufficiently since this beginning. This is where the irritation I feel kicks in; this is a good book but it could have been a better book if it had been edited more intensively. Doctoral theses need to cover as many bases as possible, even at the risk of superficiality, and everything has to be footnoted, but a good book needs a different kind of scholarly apparatus and 45 pages of tightly packed notes is more than any reader other than an examiner needs. Back in the day, British academics used to criticise the American academy for its 'publish or perish' mentality; nowadays we have gone down the same route with a vengeance, and young scholars are more or less obliged to rush out their thesis as a book as quickly as possible, which is almost always a mistake. Still, on the basis of this book one can say with some confidence that Ilan Zvi Baron is clearly one of the most interesting young international political theorists on the scene today; he has produced a very good first book - with luck he will find the space to write an even better second.

Chris Brown

Department of International Relations, London School of Economics, UK 